\title{
Genome sequence of the clover-nodulating Rhizobium leguminosarum bv. trifolii strain TA1
}

\author{
Wayne Reeve $^{* 1}$, Rui Tian ${ }^{1}$, Sofie De Meyer ${ }^{1}$, Vanessa Melino ${ }^{1}$, Jason Terpolilli ${ }^{1}$, Julie Ardley ${ }^{1}$, \\ Ravi Tiwari ${ }^{1}$, John Howieson ${ }^{1}$, Ronald Yates ${ }^{1,2}$, Graham $\mathrm{O}^{\prime} \mathrm{Hara}^{1}{ }^{1}$, Mohamed Ninawi ${ }^{1}$, Hazuki \\ Teshima ${ }^{3}$, David Bruce ${ }^{3}$, Chris Detter ${ }^{3}$, Roxanne Tapia ${ }^{3}$, Cliff Han ${ }^{3}$, Chia-Lin $\mathrm{Wei}^{3}$, Marcel \\ Huntemann ${ }^{3}$, James Han ${ }^{3}$, I-Min Chen ${ }^{5}$, Konstantinos Mavromatis ${ }^{3}$, Victor Markowitz ${ }^{5}$, \\ Natalia Ivanova ${ }^{3}$, Galina Ovchinnikova ${ }^{3}$, Ioanna Pagani ${ }^{3}$, Amrita Pati ${ }^{3}$, Lynne Goodwin ${ }^{4}$, \\ Sam Pitluck ${ }^{3}$, Tanja Woyke ${ }^{3}$ \& Nikos Kyrpides ${ }^{3}$. \\ ${ }^{1}$ Centre for Rhizobium Studies, Murdoch University, Western Australia, Australia \\ ${ }^{2}$ Department of Agriculture and Food, Western Australia, Australia \\ ${ }^{3}$ DOE Joint Genome Institute, Walnut Creek, California, USA \\ ${ }^{4}$ Los Alamos National Laboratory, Bioscience Division, Los Alamos, New Mexico, USA \\ ${ }^{5}$ Biological Data Management and Technology Center, Lawrence Berkeley National \\ Laboratory, Berkeley, California, USA
}

*Correspondence: Wayne Reeve (W.Reeve@murdoch.edu.au)

Keywords: root-nodule bacteria, nitrog en fixation, rhizobia, Alphaproteobacteria

Rhizobium leguminosarum bv. trifolii strain TA1 is an aerobic, motile, Gram-negative, nonspore-forming rod that is an effective nitrog en fixing microsymbiont on the perennial clovers originating from Europe and the Mediterranean basin. TA1 however is ineffective with many annual and perennial clovers originating from Africa and America. Here we describe the features of $R$. leguminosarum bv. trifolii strain TA1, together with genome sequence information and annotation. The $8,618,824$ bp high-quality-draft genome is arranged in a 6 scaffold of 32 contigs, contains 8,493 protein-coding genes and 83 RNA-only encoding genes, and is one of 20 rhizobial genomes sequenced as part of the DOE Joint Genome Institute 2010 Community Sequencing Prog ram.

\section{Introduction}

Biological fixation of inert atmospheric dinitrogen gas is a process that can only be performed by certain prokaryotes in the domains Archaea and Bacteria. By far the greatest amounts of nitrogen $(\mathrm{N})$ are fixed by specialized soil bacteria (root nodule bacteria or rhizobia) that form proto-cooperative, non-obligatory symbiotic relationships with legumes [1]. Indeed, these symbioses contribute $\sim 40$ million tonnes of $\mathrm{N}$ annually to support global food production [2].

Species of the legume genus Trifolium (clovers) are amongst the most widely cultivated pasture legumes. Naturally, this genus inhabits three distinct centers of diversity with approximately $28 \%$ of species in the Americas, $57 \%$ in Eurasia and $15 \%$ in Sub-Saharan Africa [3]. A smaller subset of about 30 species, almost all of Eurasian origin, are widely gown as annual and perennial species in pasture systems in Mediterranean and temperate regions [3]. Globally important perennial species of clover include $T$. repens (white clover), $T$. pratense (red clover), T. fragiferum (strawberry clover) and $T$. hybridum (alsike clover). Clovers usually form $\mathrm{N}_{2}$-fixing symbioses with the common soil bacterium Rhizobium leguminosarum bv. trifolii, and different combinations of Trifolium hosts and strains of $R$. leguminosarum bv. trifolii can vary markedly in symbiotic compatibility [4], resulting in a broad range of symbiotic developmental outcomes ranging from ineffective (nonnitrogen fixing) nodulation to fully effective $\mathrm{N}_{2}$ fixing partnerships [5].

In Australia, Rhizobium leguminosarum bv. trifolii strain TA1 (initially designated BA-Tas) has a long history of use as a commercial inoculant for Trifolium spp. [6]. TA1 was originally isolated from a root nodule on the annual species $T$. subterraneaum in Bridport, Tasmania in the early 
1950's [6]. This isolate is likely to be a naturalized strain of European origin that arrived by chance in Tasmania in the 1800's. Although widely used as a microsymbiont of European clovers, it became evident that this soil saprophyte is not acid tolerant [7] and survives poorly when coated onto clover seed with a peat based carrier [8-10]. Nevertheless, TA1 remains the commercial inoculant in Australia for perennial ( $T$ repens, $T$. pratense, $T$. fragiferum, T. hybridum, T. tumens (talish clover)) and annual (T. alexandrinum (berseem clover), $T$. glomeratum (cluster clover) and T. dubium (suckling clover)) clovers of European origin [11]. Furthermore, this $R$. leguminosarum bv. trifolii strain has been adopted by the international community as a model organism to investigate the biology of the Trifolium-Rhizobium symbiosis [12]. Here we present a summary classification and a set of general features for $R$. leguminosarum bv. trifolii strain TA1 together with the description of the complete genome sequence and its annotation.

\section{Classification and general features}

R. leguminosarum bv. trifolii strain TA1 is a motile, Gram-negative, non-spore-forming rod (Figure 1 Left and Center) in the order Rhizobiales of the class Alphaproteobacteria. It is slow growing, forming 1-4 mm diameter colonies within 3-5 days grown on half Lupin Agar ( $1 / 2 \mathrm{LA})$ [13] at $28^{\circ} \mathrm{C}$. Colonies on $1 / 2 \mathrm{LA}$ are white-opaque, slightly domed, moderately mucoid with smooth margins (Figure 1 Right). Minimum Information about the Genome Sequence (MIGS) is provided in Table 1. Figure 2 shows the phylogenetic neighborhood of $R$. leguminosarum bv. trifolii strain TA1 in a $16 \mathrm{~S}$ rRNA sequence based tree. This strain clusters closest to $R$ leguminosarum bv. trifolii $\mathrm{T} 24$ and $R$. leguminosarum bv. phaseoli RRE6 with 99.9\% and $99.8 \%$ sequence identity, respectively.

\section{Symbiotaxonomy}

Rhizobium leguminosarum bv. trifolii strain TA1 is currently the commercial inoculant for white (Trifolium repens), red (Trifolium pratense) and strawberry (Trifolium fragiferum) clovers in Australia. TA1 in general is not as effective for nitrogen fixation on annual clovers as other strains, such as WSM1325 [34,35]. However TA1 is of particular interest because it displays a broad host range for nodulation and nitrogen fixation across annual and perennial clovers originating from the European and Mediterranean centre of origin of clovers [1]. TA1 is generally able to nodulate but unable to fix with many annual and and perennial clovers originating from Africa and America [34].

\section{Genome sequencing and annotation information}

\section{Genome project history}

This organism was selected for sequencing on the basis of its environmental and agricultural relevance to issues in global carbon cycling, alternative energy production, and biogeochemical importance, and is part of the Community Sequencing Program at the U.S. Department of Energy, Joint Genome Institute (JGI) for projects of relevance to agency missions. The genome project is deposited in the Genomes OnLine Database [33] and an improved-high-quality-draft genome sequence in IMG. Sequencing, finishing and annotation were performed by the JGI. A summary of the project information is shown in Table 2.
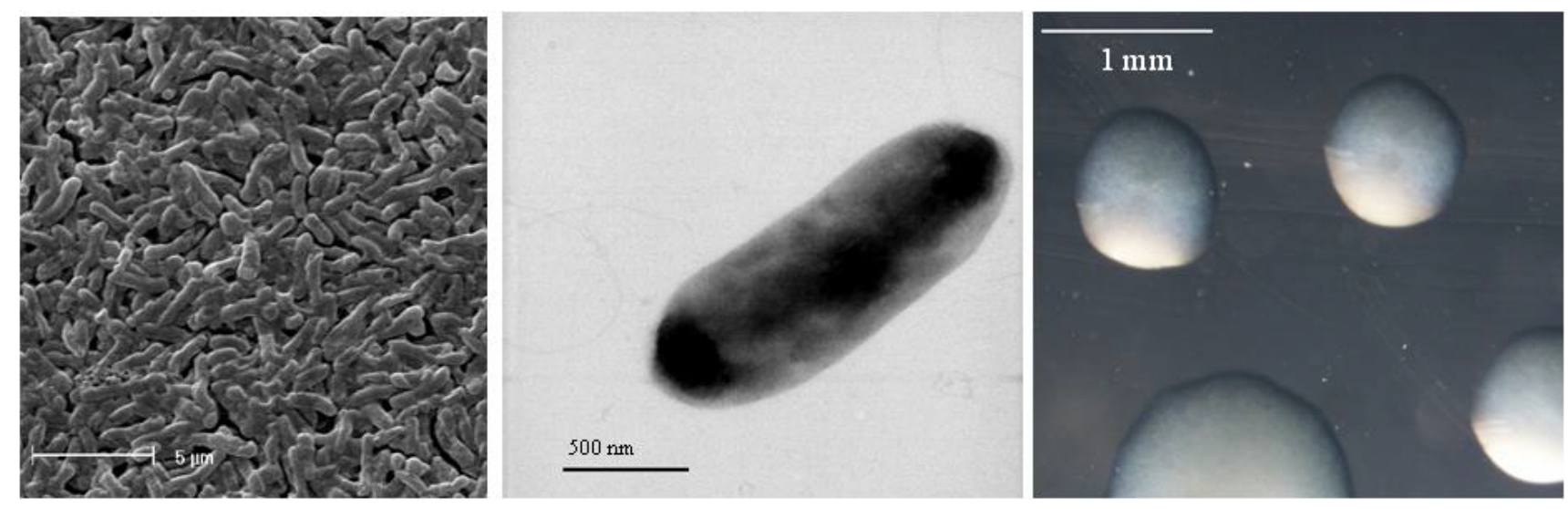

Figure 1. Images of Rhizobium leguminosarum bv. trifolii strain TA1 using scanning (Left) and transmission (Center) electron microscopy as well as light microscopy to visualize colony morphology on solid media (Right). 
Table 1. Classification and general features of Rhizobium leguminosarum bv. trifolii strain TA1 according to the MIGS recommendations [14].

\begin{tabular}{|c|c|c|c|}
\hline MIGS ID & Property & Term & Evidence code \\
\hline & & Domain Bacteria & TAS [15] \\
\hline & & Phylum Proteobacteria & TAS [16] \\
\hline & & Class Alphaproteobacteria & TAS $[17,18]$ \\
\hline & & Order Rhizobiales & TAS $[17,19]$ \\
\hline & & Family Rhizobiaceae & TAS $[20,21]$ \\
\hline & & Genus Rhizobium & TAS $[20,22-25]$ \\
\hline & Current classification & Species Rhizobium legum inosarum bv. trifolii & TAS $[20,22,25,26]$ \\
\hline & Gram stain & Negative & TAS [27] \\
\hline & Cell shape & Rod & TAS [27] \\
\hline & Motility & Motile & TAS [27] \\
\hline & Sporulation & Non-sporulating & TAS [27] \\
\hline & Temperature range & Mesophile & TAS [27] \\
\hline & Optimum temperature & $28^{\circ} \mathrm{C}$ & TAS [27] \\
\hline & Salinity & Not reported & \\
\hline \multirow[t]{3}{*}{ MIGS-22 } & Oxygen requirement & Aerobic & TAS [27] \\
\hline & Carbon source & Varied & \\
\hline & Energy source & Chemoorg anotroph & TAS [27] \\
\hline MIGS-6 & Habitat & Soil, root nodule, on host & IDA \\
\hline MIGS-15 & Biotic relationship & Free living, symbiotic & IDA \\
\hline \multirow[t]{3}{*}{ MIGS-14 } & Pathog enicity & Non-pathogenic & TAS [27] \\
\hline & Biosafety level & 1 & TAS [28] \\
\hline & Isolation & Root nodule of Trifolium subterraneum & TAS [29] \\
\hline MIGS-4 & Geographic location & Bridport, Tasmania & IDA \\
\hline MIGS-5 & Nodule collection date & 1953 & IDA \\
\hline MIGS-4.1 & Long itude & 147.667 & IDA \\
\hline MIGS-4.2 & Latitude & -41.0335 & IDA \\
\hline MIGS-4.3 & Depth & Not recorded & \\
\hline MIGS-4.4 & Altitude & Not recorded & \\
\hline
\end{tabular}

Evidence codes - IDA: Inferred from Direct Assay; TAS: Traceable Author Statement (i.e., a direct report exists in the literature). These evidence codes are from the Gene Ontology project [30]. 


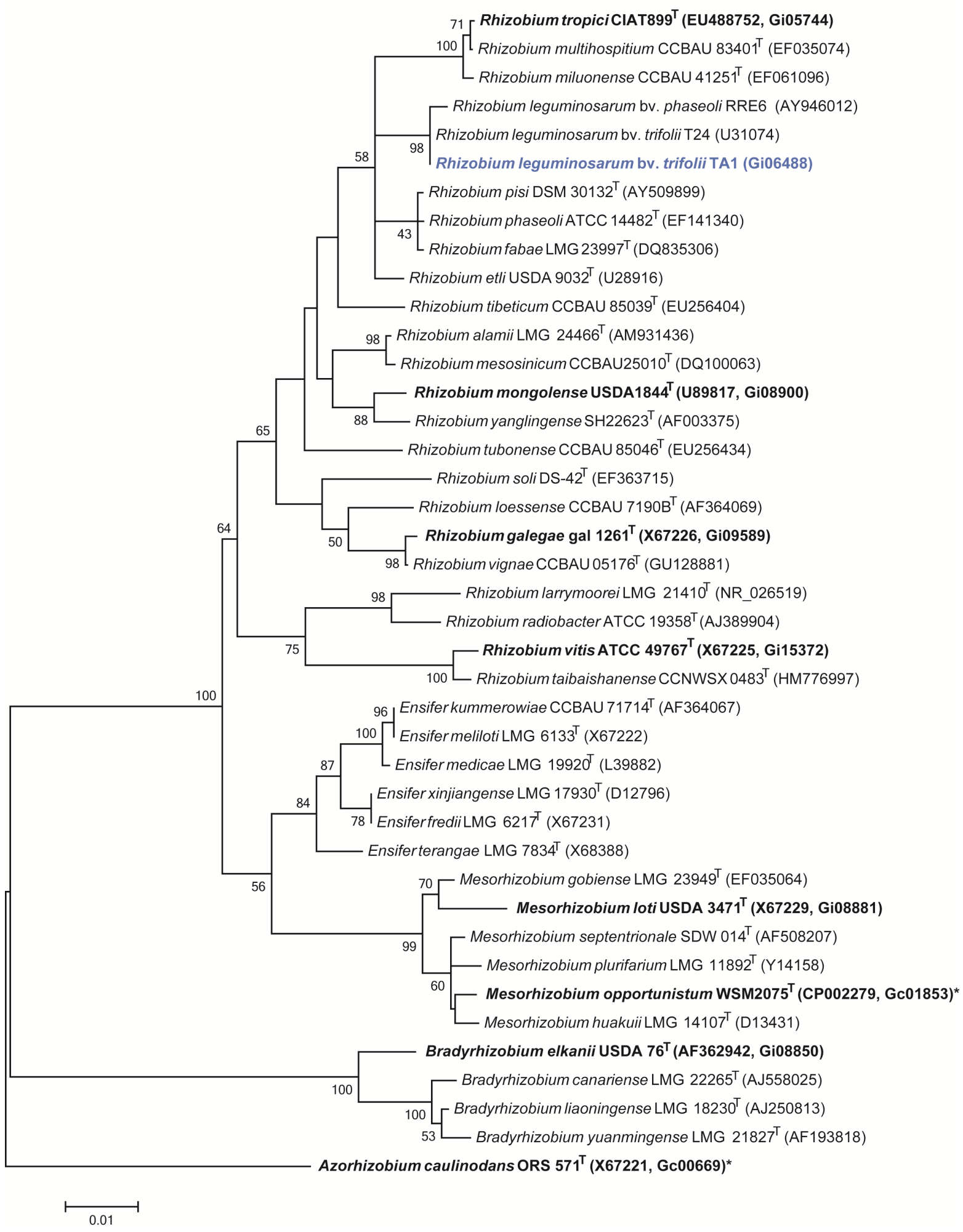

Figure 2. Phylogenetic tree showing the relationship of Rhizobium leguminosarum bv. trifolii strain TA1 (shown in blue print) with some of the root nodule bacteria in the order Rhizobiales based on aligned sequences of the $16 \mathrm{~S}$ rRNA gene (1,307 bp internal region). All sites were informative and there were no gapcontaining sites. Phylogenetic analyses were performed using MEGA, version 5.05 [31]. The tree was built using the maximum likelihood method with the General Time Reversible model. Bootstrap analysis [32] with 500 replicates was performed to assess the support of the clusters. Type strains are indicated with a superscript T. Strains with a genome sequencing project registered in GOLD [33] are in bold print and the GOLD ID is mentioned after the accession number. Published genomes are desig nated with an asterisk. 
Table 2. Genome sequencing project information for Rhizobium leguminosarum bv. trifolii strain TA1.

\begin{tabular}{lll}
\hline MIGS ID & Property & Term \\
\hline MIGS-31 & Finishing quality & Improved hig h-quality draft \\
MIGS-28 & Libraries used & Illumina GAii shotg un and paired end 454 libraries \\
MIGS-29 & Sequencing platforms & Illumina GAii and 454 GS FLX Titanium technologies \\
MIGS-31.2 & Sequencing coverage & $7.8 \times 454$ paired end, 764.2 × Illumina \\
MIGS-30 & Assemblers & Velvet 1.0.13, Newbler 2.3, phrap 4.24 \\
MIGS-32 & Gene calling methods & Prodigal 1.4, GenePRIMP \\
& GOLD ID & Gi0648 \\
& NCBI project ID & 63831 \\
& Database: IMG & 2510461076 \\
& Project relevance & Symbiotic $\mathrm{N}_{2}$ fixation, ag riculture \\
\hline
\end{tabular}

\section{Growth conditions and DNA isolation}

Rhizobium leguminosarum bv. trifolii strain TA1 was grown to mid logarithmic phase in TY rich media [36] on a gyratory shaker at $28^{\circ} \mathrm{C}$. DNA was isolated from $60 \mathrm{ml}$ of cells using a CTAB (Cetyl trimethyl ammonium bromide) bacterial genomic DNA isolation method [37].

\section{Genome sequencing and assembly}

The genome of Rhizobium leguminosarum bv. trifolii strain TA1 was sequenced at the Joint Genome Institute (JGI) using a combination of Illumina [38] and 454 technologies [39]. An Illumina GAii shotgun library which generated $66,421,308$ reads totaling 5,048 $\mathrm{Mb}$, and a paired end 454 library with an average insert size of 13 $\mathrm{kb}$ which generated 393,147 reads totaling 100.1 $\mathrm{Mb}$ of 454 data were generated for this genome. All general aspects of library construction and sequencing performed at the JGI can be found at the JGI user homepage [40]. The initial draft assembly contained 199 contigs in 5 scaffolds. The 454 paired end data was assembled with Newbler, version 2.3. The Newbler consensus sequences were computationally shredded into 2 $\mathrm{kb}$ overlapping fake reads (shreds). Illumina sequencing data were assembled with VELVET, version 1.0.13 [41], and the consensus sequence were computationally shredded into $1.5 \mathrm{~kb}$ overlapping fake reads (shreds). We integrated the 454 Newbler consensus shreds, the Illumina VELVET consensus shreds and the read pairs in the 454 paired end library using parallel phrap, version SPS - 4.24 (High Performance Software, LLC). The software Consed [42-44] was used in the following finishing process. Illumina data was used to correct potential base errors and increase consensus quality using the software Polisher developed at JGI (Alla Lapidus, unpublished). Possible mis-assemblies were corrected using gapResolution (Cliff Han, unpublished), Dupfinisher (Han, 2006), or sequencing cloned bridging PCR fragments with subcloning. Gaps between contigs were closed by editing in Consed, by PCR and by Bubble PCR (J-F Cheng, unpublished) primer walks. A total of 275 additional reactions were necessary to close gaps and to raise the quality of the finished sequence. The estimated genome size is $7.6 \mathrm{Mb}$ and the final assembly is based on $65.3 \mathrm{Mb}$ of 454 draft data which provides an average of $8.6 \times$ coverage of the genome and $4,864.7 \mathrm{Mb}$ of Illumina draft data which provides an average $640.1 \times$ coverage of the genome.

\section{Genome annotation}

Genes were identified using Prodigal [45] as part of the DOE-JGI Annotation pipeline [46], followed by a round of manual curation using the JGI GenePRIMP pipeline [47]. The predicted CDSs were translated and used to search the National Center for Biotechnology Information (NCBI) nonredundant database, UniProt, TIGRFam, Pfam, 
PRIAM, KEGG, COG, and InterPro databases. These data sources were combined to assert a product description for each predicted protein. Noncoding genes and miscellaneous features were predicted using tRNAscan-SE [48], RNAMMer [49], Rfam [50], TMHMM [51], and SignalP [52]. Additional gene prediction analyses and functional annotation were performed within the Integrated Microbial Genomes (IMG-ER) platform $[37,53]$.

\section{Genome properties}

The genome is 8,618,824 nucleotides with $60.74 \%$ GC content (Table 3 ) and comprised of 32 contigs in 6 scaffolds (Figure 3). From a total of 8,576 genes, 8,493 were protein encoding and 83 RNA only encoding genes. The majority of genes $(77.85 \%)$ were assigned a putative function whilst the remaining genes were annotated as hypothetical. The distribution of genes into COGs functional categories is presented in Table 4 .

Table 3. Genome sequencing project information for Rhizobium leguminosarum bv. trifolii strain SRDI943.

\begin{tabular}{|c|c|c|}
\hline Attribute & Value & $\%$ of Total \\
\hline Genome size (bp) & $8,618,824$ & 100.00 \\
\hline DNA coding region $(b p)$ & $7,407,820$ & 85.95 \\
\hline DNA G+C content $(b p)$ & $5,234,677$ & 60.74 \\
\hline Number of scaffolds & 6 & \\
\hline Number of contigs & 32 & \\
\hline Total genes & 8,576 & 100.00 \\
\hline RNA genes & 83 & 0.97 \\
\hline rRNA operons* & 1 & 0.01 \\
\hline Protein-coding genes & 8,493 & 99.03 \\
\hline Genes with function prediction & 6,676 & 77.85 \\
\hline Genes assig ned to COGs & 6,673 & 77.81 \\
\hline Genes assig ned Pfam domains & 6,944 & 80.97 \\
\hline Genes with signal peptides & 727 & 8.48 \\
\hline Genes with transmembrane helices & 1,897 & 22.12 \\
\hline CRISPR repeats & 0 & \\
\hline
\end{tabular}

* 1 copy of $23 \mathrm{~S}$ rRNA, 2 copies of $16 \mathrm{~S}$ and 2 copies of $5 \mathrm{~S}$ rRNA genes 
RLF.1

(1)

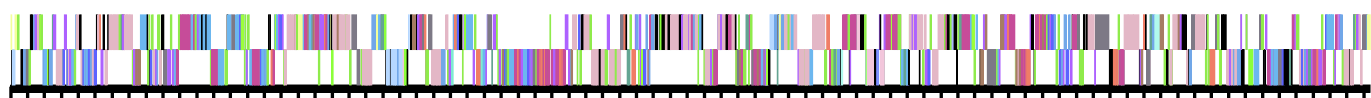

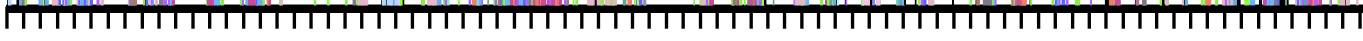

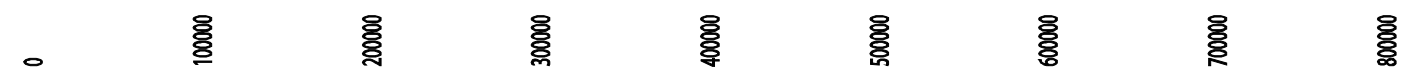

RLF.2
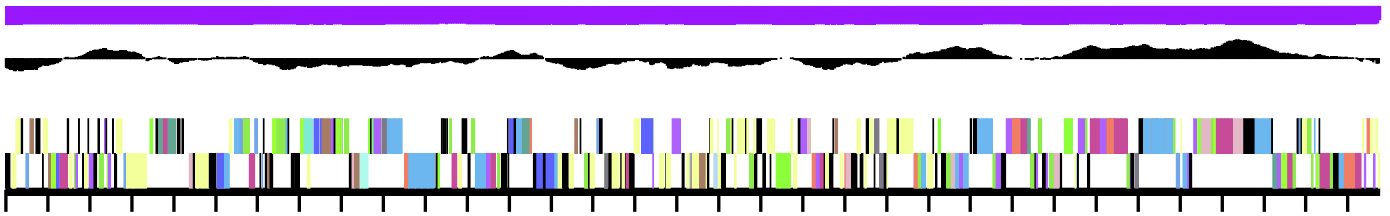

홍

हूํํ

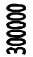

RLF.3

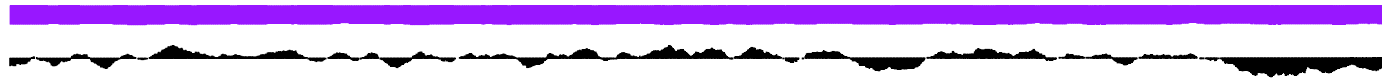

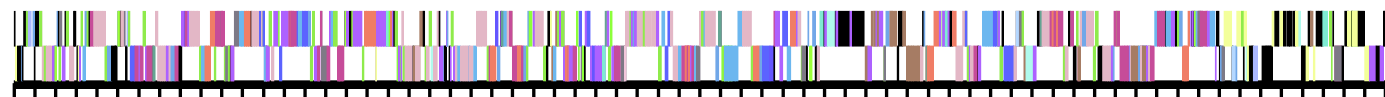

RLF.4
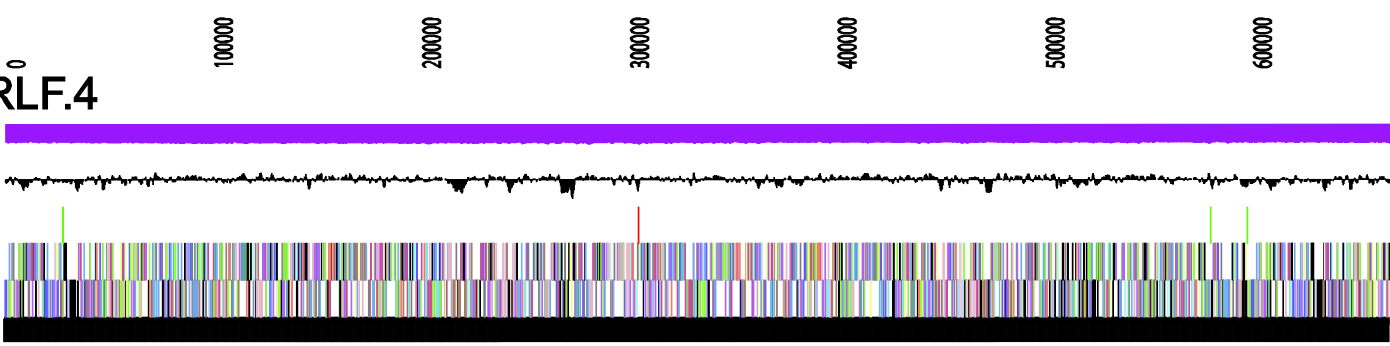

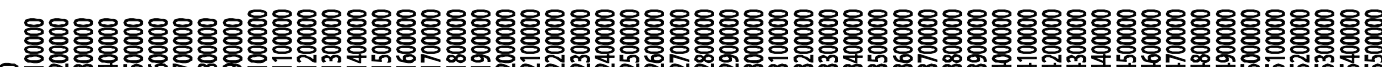

RLF.5
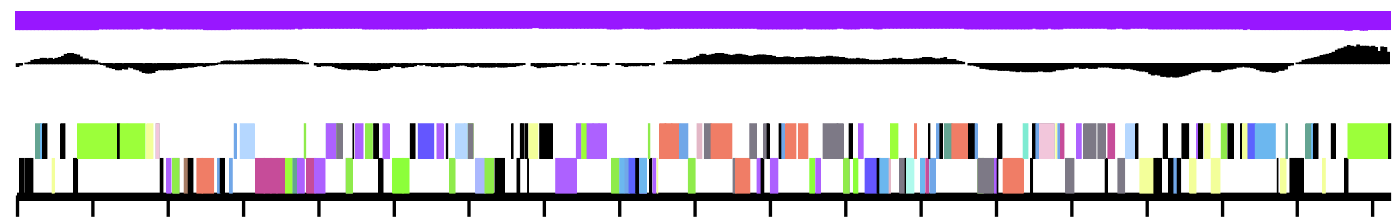

RLF.6

\&

홍

艿

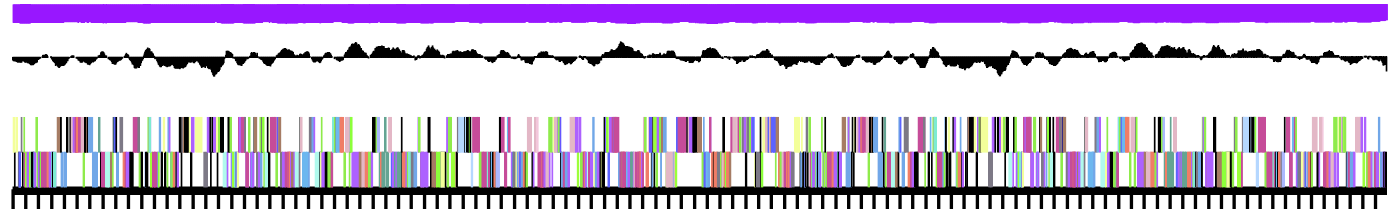

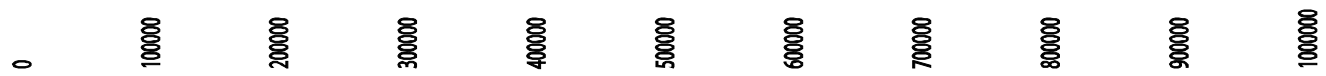

Figure 3. Graphical linear map of the genome of Rhizobium leguminosarum bv. trifolii strain TA1. From outside to the center: Genes on forward strand (color by COG categ ories), Genes on reverse strand (color by COG categories), RNA genes (tRNAs green, sRNAs red, other RNAs black), GC content, GC skew. 
Table 4. Number of protein coding genes of Rhizob ium le guminosarum bv. trifolii TA1 associated with the general COG functional categories.

\begin{tabular}{|c|c|c|c|}
\hline Code & Value & \%age & COG Categ ory \\
\hline$J$ & 247 & 3.29 & Translation, ribosomal structure and biogenesis \\
\hline A & 1 & 0.01 & RNA processing and modification \\
\hline K & 751 & 10.01 & Transcription \\
\hline $\mathrm{L}$ & 317 & 4.23 & Replication, recombination and repair \\
\hline B & 3 & 0.04 & Chromatin structure and dynamics \\
\hline $\mathrm{D}$ & 44 & 0.59 & Cell cycle control, mitosis and meiosis \\
\hline $\mathrm{Y}$ & 0 & 0.00 & Nuclear structure \\
\hline V & 92 & 1.23 & Defense mechanisms \\
\hline $\mathrm{T}$ & 402 & 5.36 & Signal transduction mechanisms \\
\hline M & 365 & 4.87 & Cell wall/membrane biog enesis \\
\hline $\mathrm{N}$ & 100 & 1.33 & Cell motility \\
\hline Z & 2 & 0.03 & Cytoskeleton \\
\hline W & 0 & 0.00 & Extracellular structures \\
\hline$U$ & 114 & 1.52 & Intracellular trafficking and secretion \\
\hline $\mathrm{O}$ & 217 & 2.89 & Posttranslational modification, protein turnover, chaperones \\
\hline $\mathrm{C}$ & 384 & 5.12 & Energy production conversion \\
\hline G & 746 & 9.95 & Carbohydrate transport and metabolism \\
\hline $\mathrm{E}$ & 803 & 10.71 & Amino acid transport metabolism \\
\hline $\mathrm{F}$ & 134 & 1.79 & Nucleotide transport and metabolism \\
\hline $\mathrm{H}$ & 235 & 3.13 & Coenzyme transport and metabolism \\
\hline I & 271 & 3.61 & Lipid transport and metabolism \\
\hline $\mathrm{P}$ & 374 & 4.99 & Inorganic ion transport and metabolism \\
\hline Q & 201 & 2.68 & Secondary metabolite biosynthesis, transport and catabolism \\
\hline $\mathrm{R}$ & 976 & 13.02 & General function prediction only \\
\hline $\mathrm{S}$ & 720 & 9.60 & Function unknown \\
\hline- & 1,903 & 22.19 & Not in COGS \\
\hline
\end{tabular}




\section{Acknowledgements}

This work was perform ed under the aus pices of the US Department of Energy's Office of Science, Biological and Environmental Research Program, and by the University of California, Lawrence Berkeley National Laboratory under contract No. DE-AC02-05CH11231, Lawrence Livermore National Laboratory under Contract No. DEAC52-07NA27344, and Los Alamos National Laboratory under contract No. DE-AC02-06NA25396. We gratefully acknowledge the funding received from the Mur-

\section{References}

1. O'Hara GW. The role of nitrogen fixation in crop production. J Crop Prod 1998; 1:115-138. http://dx.doi.org/10.1300/J144v01n02_06

2. Herridge DF, Peoples MB, Boddey RM. Global inputs of biological nitrogen fixation in agricultural systems. Plant Soil 2008; 311:1-18. http://dx.doi.org/10.1007/s11104-008-9668-3

3. Lamont EJ, Zoghlami A, Hamilton RS, Bennett SJ. Clovers (Trifolium L.). In: Maxted N, Bennett SJ, editors. Plant Genetic Resources of Legumes in the Mediterranean. Dordrecht: Kluwer Academic Publishers; 2001. p 79-98.

4. Howieson J, Yates R, O'Hara G, Ryder M, Real D. The interactions of Rhizobium leguminosarum biovar trifolii in nodulation of annual and perennial Trifolium spp.from diverse centres of orig in. Aust J Exp Agric 2005; 45:199-207. http://dx.doi.org/10.1071/EA03167

5. Melino VJ, Drew EA, Ballard RA, Reeve WG, Thomson G, White RG, O'Hara GW. Identifying abnormalities in symbiotic development between Trifolium spp. and Rhizobium legum inosarum bv. trifolii leading to sub-optimal and ineffective nodule phenotypes. Ann Bot 2012; 110:1559-1572. PubMed http://dx.doi.org/10.1093/aob/mcs206

6. Bullard GK, Roughley RJ, Pulsford DJ. The legume inoculant industry and inoculant quality control in Australia: 1953-2003. Aust J Exp Agric 2005; 45:12 7-140. http://dx.doi.org/10.1071/EA03159

7. Watkin E, O'Hara G, Howieson JG, Glenn AR. Identification of tolerance to soil acidity in inoculant strains of Rhizobium le guminosarum bv. trifolii. Soil Biol Biochem 2000; 32:1393-1403. http://dx.doi.org/10.1016/S0038-0717(00)00057$\underline{2}$

8. Deaker R, Roughley RJ, Kennedy IR. Legume seed inoculation technology: a review. Soil Biol Biochem 2004; 36:1275-1288. http://dx.doi.org/10.1016/j.soilbio.2004.04.009 doch University Strategic Research Fund through the Crop and Plant Research Institute (CaPRI) and the Centre for Rhizobium Studies (CRS) at Murdoch University. The authors would like to thank the Australia-China Joint Research Centre for Wheat Improvem ent (ACCWI) and SuperSeed Technologies (SST) for financially supporting Moham ed Ninawi's PhD project.

9. Deaker R, Roughley RJ, Kennedy IR. Desiccation tolerance of rhizobia when protected by synthetic polymers. Soil Biol Biochem 2007; 39:573-580. http://dx.doi.org/10.1016/j.soilbio.2006.09.005

10. Hartley E, Gemell G, Deaker R. Some factors that contribute to poor survival of rhizobia on preinoculated leg ume seed. Crop Pasture Sci 2012; 63:858-865. http://dx.doi.org/10.1071/CP12132

11. Drew EA, Herridge DF, Ballard RA, O'Hara GW, Deaker R, Denton MD, Yates RJ, Gemell G, Hartley $\mathrm{E}$, Phillips L, et al. Inoculating legumes: a practical guide. Grains Research and Development Corporation; 2012.

12. Unkovich MJ. Nitrogen fixation in Australian dairy systems: review and prospect. Crop Pasture Sci 2012; 63:787-804. http://dx.doi.org/10.1071/CP12180

13. Howieson JG, Ewing MA, D'antuono MF. Selection for acid tolerance in Rhizobium meliloti. Plant Soil 1988; 105:179-188. http://dx.doi.org/10.1007/BF02376781

14. Field D, Garrity G, Gray T, Morrison N, Seleng ut J, Sterk P, Tatusova T, Thomson N, Allen M, Angiuoli SV, et al. Towards a richer description of our complete collection of genomes and metagenomes "Minimum Information about a Genome Sequence " (MIGS) specification. Nat Biotechnol 2008; 26:541-547. PubMed http://dx.doi.org/10.1038/nbt1360

15. Woese CR, Kandler O, Wheelis ML. Towards a natural system of organisms: proposal for the domains Archaea, Bacteria, and Eucarya. Proc Natl Acad Sci USA 1990; 87:457 6-4579. PubMed http://dx.doi.org/10.1073/pnas.87.12.4576

16. Garrity GM, Bell JA, Lilburn T. Phylum XIV. Proteobacteria phyl. nov. In: Garrity GM, Brenner DJ, Krieg NR, Staley JT (eds), Bergey's Manual of 
Systematic Bacteriology, Second Edition, Volume 2, Part B, Springer, New York, 2005, p. 1.

17. Editor L. Validation List No. 107. List of new names and new combinations previously effectively, but not validly, published. Int I Syst Evol Microbiol 2006; 56:1-6. PubMed http://dx.doi.org/10.1099/ijs.0.64188-0

18. Garrity GM, Bell JA, Lilburn T. Class I. Alphaproteobacteria class. nov. In: Garrity GM, Brenner DJ, Krieg NR, Staley JT (eds), Bergey's Manual of Systematic Bacteriology, Second Edition, Volume 2, Part C, Springer, New York, 2005, p. 1.

19. Garrity GM, Bell JA, Lilburn T. Class I. Alphaproteobacteria class. In: Garrity GM, Brenner DJ, Kreig NR, Staley JT, editors. Bergy's Manual of Systematic Bacteriology. Second ed: New York: Spring er - Verlag; 2005.

20. Skerman VBD, McGowan V, Sneath PHA. Approved Lists of Bacterial Names. Int J Syst Bacteriol 1980; 30:225-420. http://dx.doi.org/10.1099/00207713-30-1-225

21. Conn HJ. Taxonomic relationships of certain nonsporeforming rods in soil. / Bacterio/ 1938; 36: $320-321$.

22. Frank B. Über die Pilzsymbiose der Leguminosen. Ber Dtsch Bot Ges 1889; 7:332-346.

23. Jordan DC, Allen ON. Genus I. Rhizobium Frank 1889, 338; Nom. gen. cons. Opin. 34, Jud. Comm. 1970, 11. In: Buchanan RE, Gibbons NE (eds), Bergey's Manual of Determinative Bacteriology, Eighth Edition, The Williams and Wilkins Co., Baltimore, 1974, p. 262-264.

24. Young JM, Kuykendall LD, Martínez-Romero E, Kerr A, Sawada H. A revision of Rhizobium Frank 1889, with an emended description of the genus, and the inclusion of all species of Agrobacterium Conn 1942 and Allorhizobium undicola de Lajudie et al. 1998 as new combinations: Rhizobium radiobacter, $R$. rhizogenes, $R$. rubi, $R$. undic ola and $R$. vitis. Int I Syst Evol Microbiol 2001; 51:89-103. PubMed

25. Editorial Secretary (for the Judicial Commission of the International Committee on Nomenclature of Bacteria). OPINION 34: Conservation of the Generic Name Rhizobium Frank 1889. Int J Syst Bacteriol 1970; 20:11-12. http://dx.doi.org/10.1099/00207713-20-1-11

26. Ramírez-Bahena $M H$, García-Fraile $P$, Peix $A$, Valverde A, Rivas R, Igual JM, Mateos PF, Martínez-Molina E, Velázquez E. Revision of the taxonomic status of the species Rhizobium legum inosarum (Frank 1879) Frank 1889AL, Rhizobium phaseoli Dangeard 1926AL and Rhizobium trifolii Dangeard 1926AL. R. trifolii is a later synonym of $R$. leguminosarum. Reclassification of the strain $R$. leguminosarum DSM 30132 (=NCIMB 11478) as Rhizobium pisisp. nov. Int J Syst Evol Microbiol 2008; 58:2484-2490. PubMed http://dx.doi.org/10.1099/ijs.0.65621-0

27. Kuykendall LD, Young JM, Martínez-Romero E, Kerr A, Sawada H. Genus I. Rhizobium. In: Garrity GM, Brenner DJ, Krieg NR, Staley JT, editors. Bergey's Manual of Systematic Bacteriology. Second ed. Volume 2. New York: Springer Verlag; 2005.

28. Agents B. Technical rules for biological agents. TRBA (http://www.baua.de):466.

29. Brockwell J, Mcllroy RA, Hebb DM. The Australian collection of Rhizobium strains for temperate leg umes catalog ue. CSIRO Plant Industry (Australia); 1998.164 p.

30. Ashburner M, Ball CA, Blake JA, Botstein D, Butler $\mathrm{H}$, Cherry JM, Davis AP, Dolinski K, Dwight SS, Eppig JT, et al. Gene ontology: tool for the unification of biology. The Gene Ontology Consortium. Nat Genet 2000; 25:25-29. PubMed http://dx.doi.org/10.1038/75556

31. Tamura K, Peterson D, Peterson N, Stecher G, Nei M, Kumar S. MEGA5: molecular evolutionary genetics analysis using maximum likelihood, evolutionary distance, and maximum parsimony methods. Mol Biol Evol 2011; 28:2731-2739. $\underline{\text { PubMed }}$ http://dx.doi.org/10.1093/molbev/msr121

32. Felsenstein J. Confidence limits on phylog enies: an approach using the bootstrap. Evolution 1985; 39:783-791. http://dx.doi.org/10.2307/2408678

33. Liolios K, Mavromatis K, Tavernarakis N, Kyrpides NC. The Genomes On Line Database (GOLD) in 2007: status of genomic and metagenomic projects and their associated metadata. Nucleic Acids Res 2008; 36(Database issue):D475-D479. PubMed http://dx.doi.org/10.1093/nar/g km884

34. Howieson J, Yates R, O'Hara G, Ryder M, Real D. The interactions of Rhizobium leguminosarum biovar trifolii in nodulation of annual and perennial Trifolium spp.from diverse centres of origin. Aust J Exp Agric 2005; 45:199-207. http://dx.doi.org/10.1071/EA03167

35. Reeve W, O'Hara G, Chain P, Ardley J, Brau L, Nandesena K, Tiwari R, Copeland A, Nolan M, Han C, et al. Complete genome sequence of Rhi- 
zobium le guminosarum bv. trifolii strain WSM1325, an effective microsymbiont of annual Mediterranean clovers. Stand Genomic Sci 2010; 2:347-356. $\underline{\text { PubMed }}$ http://dx.doi.org/10.4056/sigs.852027

36. Reeve WG, Tiwari RP, Worsley PS, Dilworth MJ, Glenn AR, Howieson JG. Constructs for insertional mutagenesis, transcriptional signal localization and gene regulation studies in root nodule and other bacteria. Microbiology 1999; 145:1307-1316. PubMed http://dx.doi.org/10.1099/13500872-145-6-1307

37. DOE Joint Genome Institute. http://my.jgi.doe.gov/g eneral/index.html

38. Bennett S. Solexa Ltd. Pharmacogenomics 2004; 5:433-438. PubMed http://dx.doi.org/10.1517/14622416.5.4.433

39. Margulies M, Eg holm M, Altman WE, Attiya S, Bader JS, Bemben LA, Berka J, Braverman MS, Chen YJ, Chen Z, et al. Genome sequencing in microfabricated high-density picolitre reactors. Nature 2005; 437:376-380. PubMed

40. DOE Joint Genome Institute. http://my.jgi.doe.gov/g eneral/index.html

41. Zerbino DR. Using the Velvet de novo assembler for short-read sequencing technolog ies. Current Protocols in Bioinformatics 2010; Chapter 11:Unit 115.

42. Ewing B, Green P. Base-calling of automated sequencer traces using phred. II. Error probabilities. Genome Res 1998; 8:186-194. PubMed http://dx.doi.org/10.1101/gr.8.3.175

43. Ewing B, Hillier L, Wendl MC, Green P. Basecalling of automated sequencer traces using phred. I. Accuracy assessment. Genome Res 1998; 8:175-185. PubMed http://dx.doi.org/10.1101/gr.8.3.175

44. Gordon D, Abajian C, Green P. Consed: a graphical tool for sequence finishing. Genome Res 1998; 8:195-202. $\underline{\text { PubMed }}$ http://dx.doi.org/10.1101/gr.8.3.195

45. Hyatt D, Chen GL, Locascio PF, Land ML, Larimer FW, Hauser LJ. Prodigal: prokaryotic gene recognition and translation initiation site identifi- cation. BMC Bioinformatics 2010; 11:119. Pub-

Med http://dx.doi.org/10.1186/1471-2105-11-119

46. Mavromatis K, Ivanova NN, Chen IM, Szeto E, Markowitz VM, Kyrpides NC. The DOE-JGI Standard operating procedure for the annotations of microbial genomes. Stand Genomic Sci 2009; 1:63-67. PubMed http://dx.doi.org/10.4056/sigs.632

47. Pati A, Ivanova NN, Mikhailova N, Ovchinnikova G, Hooper SD, Lykidis A, Kypides NC.

GenePRIMP: a gene prediction improvement pipeline for prokaryotic genomes. Nat Methods 2010; 7:455-457. $\underline{\text { PubMed }}$ http://dx.doi.org/10.1038/nmeth.1457

48. Lowe TM, Eddy SR. tRNAscan-SE: a prog ram for improved detection of transfer RNA genes in genomic sequence. Nucleic Acids Res 1997; 25:955-964. PubMed

49. Lagesen K, Hallin P, Rodland EA, Staerfeldt HH, Rognes T, Ussery DW. RNAmmer: consistent and rapid annotation of ribosomal RNA genes. Nucleic Acids Res 2007; 35:3100-3108. PubMed http://dx.doi.org/10.1093/nar/gkm160

50. Griffiths-Jones S, Bateman A, Marshall M, Khanna A, Eddy SR. Rfam: an RNA family database. Nucleic Acids Res 2003; 31:439-441. PubMed http://dx.doi.org/10.1093/nar/g kg 006

51. Krogh A, Larsson B, von Heijne G, Sonnhammer EL. Predicting transmembrane protein topology with a hidden Markov model: application to complete genomes. J Mol Biol 2001; 305:567580. PubMed http://dx.doi.org/10.1006/jmbi.2000.4315

52. Bendtsen JD, Nielsen H, von Heijne G, Brunak S. Improved prediction of signal peptides: SignalP 3. 0. J Mol Biol 2004; 340:783-795. PubMed http://dx.doi.org/10.1016/j.jmb.2004.05.028

53. Markowitz VM, Mavromatis K, Ivanova NN, Chen IM, Chu K, Kyrpides NC. IMG ER: a system for microbial genome annotation expert review and curation. Bioinformatics 2009; 25:22 71-22 78.

$\underline{\text { PubMed }}$

http://dx.doi.org/10.1093/bioinformatics/btp393 